\title{
Validation of MODIS derived aerosol optical depth and an investigation on aerosol transport over the South East Arabian Sea during ARMEX-II
}

\author{
M. Aloysius, M. Mohan, S. Suresh Babu, K. Parameswaran, and K. Krishna Moorthy \\ Space Physics Laboratory, Vikram Sarabhai Space Centre, Indian Space Research Organisation, Trivandrum - 695 022, India
}

Received: 7 July 2008 - Revised: 26 January 2009 - Accepted: 31 March 2009 - Published: 8 June 2009

\begin{abstract}
The influence of wind and humidity on aerosol optical depth (AOD) over the Arabian sea is being investigated using MODIS (Moderate Resolution Imaging Spectroradiometer) Level 3 (Collection-5) and NCEP (National Centres for Environmental Prediction) reanalysis data for the second phase of the Arabian Sea Monsoon Experiment (ARMEX-II) over the South East Arabian Sea (SEAS) in the pre-monsoon period (14 March-10 April 2003). In order to qualify MODIS data for this study, MODIS aerosol parameters were first compared with ship borne Microtops measurements. This showed correlations $0.96-0.97$ in the case of spectral AODs and a correlation 0.72 for the angstrom exponents. The daily AOD data from MODIS and winds from NCEP reveal that the ship observed episodic enhancement and decay of AOD at the TSL (Time Series Location) during 23 March-6 April 2003 was caused by the southward drift of an aerosol pocket driven by an intensification and reduction of surface pressure in the North Western Arabian Sea with a low altitude convergence prevailing over SEAS. The AOD increase coincided with a decrease in the Angstrom exponent and the fine mode fraction suggesting the pocket being dominated by coarse mode particles. A partial correlation analysis reveals that the lower altitude wind convergence is the most influential atmospheric variable in modulating AOD over the ARMEX-II domain during the TSL period. However, surface winds at a distant zone in the north/north west upwind direction also had a moderate influence, though with a lag of two days. But this effect was minor since the winds were not strong enough to produce marine aerosols matching with the high AODs over the ARMEX-II domain. These findings and the similarity between MODIS column mass concentration and the ship borne QCM (Quartz Crystal Microbalance) measured coarse mode mass concentration, suggest that the
\end{abstract}

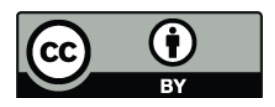

Correspondence to: M. Mohan (mannil_mohan@vssc.gov.in) aerosol pocket was mostly composed of coarse mode mineral dust in the lower atmospheric altitudes transported from the Arabian deserts.

Keywords. Atmospheric composition and structure (Aerosols and particles) - Meteorology and atmospheric dynamics (Synoptic-scale meteorology) - Radio science (Remote sensing)

\section{Introduction}

Atmospheric aerosols play a significant role in the earth's climate by perturbing the radiation energy balance of the earthatmosphere system (Charlson et al., 1992; Andreae, 1995; Hansen et al., 1997; Boucher et al., 1998; Haywood and Boucher, 2000; IPCC, 2001). The scattering and absorption of solar (short wave) and terrestrial (long wave) radiation by aerosols, known as the direct effect, can cool the Earth's surface while simultaneously warming the atmosphere leading to a perturbation of the vertical temperature structure of the atmosphere (Coakley et al., 1983; Charlson et al., 1992; Menon et al., 2002). The indirect effect of aerosols is to influence the radiative properties and lifetime of clouds (Twomey, 1977; Albrecht, 1989; Boucher et al., 1998) through microphysical processes. In contrast to the well-mixed greenhouse gases, whose concentration is fairly uniform all over the globe, the physical and chemical properties of aerosols show a pronounced variation at short spatial and temporal scales. Because of this, a comprehensive knowledge of the aerosol distribution is essential for making a quantitative assessment of the aerosol impact on climate change. In recent years, with the aim of acquiring high quality data through multi instrumental field campaigns involving large networks of ground stations, ships, aircrafts and space borne sensors (Prospero, 1979; Satheesh and Moorthy, 1997; Bates et al., 1998; Holben et al., 1998; Moorthy and Satheesh, 2000; Raes et al.,

Published by Copernicus Publications on behalf of the European Geosciences Union. 
2000; Jayaraman et al., 2001; Ramanathan et al., 2001; Li and Ramnathan, 2002; Smirnov et al., 2002), the aerosol characterization activity have been strengthened in the global scenario. Ground based observations on aerosols, capable of achieving accurate data on aerosol properties, have poor spatial resolution as they are generally made from widely separated locations. But the low earth orbiting aerosol remote sensing satellites have the capability of contiguous coverage over a large region at frequent intervals (typically, once a day). Because of this, satellite remote sensing is the most ideal technique for studying aerosol dynamics and long range transport (Martonchik, 1997; King et al., 1999; Kaufman et al., 2002; Mishchenko et al., 2004). However, the reliability of aerosol products from space-borne sensors have to be constantly assessed through proper validations over land as well as ocean. Based on these findings, the aerosol retrieval algorithms must be upgraded regularly (Chu et al., 2002; Remer et al., 2002, 2005) to improve the quality of the satellite data products.

Every year the Indian landmass and the surrounding oceanic regions experience a sequence of contrasting meteorological conditions accompanied by large-scale transformations in wind systems and air mass. The strong seasonal variations, together with the characteristic topography of the Indian subcontinent and a host of natural and anthropogenic sources, make this a unique region over the globe from the perspective of aerosol studies (Moorthy and Saha, 2000; Moorthy and Satheesh, 2000; Satheesh and Srinivasan, 2002). Though most of the aerosols generated from the surface remain confined to the planetary boundary layer, a significant amount is lifted up into the free troposphere and carried over long distances by the winds. This long range transport can modify aerosol properties such as their concentration, size distribution and chemical composition (Jennings and O'Dowd, 1990; Krishnamurti et al., 1998; Moorthy et al., 2005). Observations during the INDOEX (Indian Ocean Experiment, 1998) and the ARMEX-I (in 2001) have shown that the atmosphere over the Arabian Sea is strongly influenced by aerosols from west Asia, Africa and east/south east Asia brought by winds (Moorthy and Saha, 2000; Li and Ramnathan, 2002; Vinoj and Satheesh, 2003; Suresh Babu et al., 2004; Nair et al., 2005).

The MODIS (Moderate Resolution Imaging Spectroradiometer) onboard EOS Terra (10:30 a.m., equatorial crossing) and Aqua (1:30 p.m., equatorial crossing) satellites launched in 1999 and 2002, respectively, having seven calibrated spectral channels in the wavelength range 470$2100 \mathrm{~nm}$ with spatial resolution in the range $250-500 \mathrm{~m}$ has initiated a new era in aerosol remote sensing (Kaufman et al., 1997a, b; Tanre et al., 1997; King et al., 1999). This satellite pair continuously monitors aerosols over the ocean and land with nearly full global coverage on a daily basis (Kaufman et al., 2000). Aerosol parameters provided by MODIS include spectral AOD (at wavelengths 470, 550 and $660 \mathrm{~nm}$ over land and at wavelengths $470,550,660,865,1200,1600$ and $2100 \mathrm{~nm}$ over ocean), angstrom exponent (one value over land generated using wavelengths 470 and $660 \mathrm{~nm}$ and two values over the ocean, one generated using 550 and $865 \mathrm{~nm}$ in the small wavelength range and the other using 865 and $2100 \mathrm{~nm}$ in the long wavelength range), fine mode fraction (FMF) and aerosol mass concentration. FMF is the ratio of small-mode AOD to the total AOD at $550 \mathrm{~nm}$, where the small mode and coarse mode particles are defined such that their effective radii are in the range $0.1-0.25 \mu \mathrm{m}$ and 1.0 $2.5 \mu \mathrm{m}$, respectively (Jones and Christopher, 2007). Though the quality of data over land and ocean has been validated at several locations over the globe (Chu et al., 2002; Ichoku et al., 2002a; Remer et al., 2002, 2005), such exercises are scant over the Indian regions. While there have been a few attempts for validating the data products over the Bay of Bengal (Vinoj et al., 2004), such efforts over the Arabian Sea have hardly been reported.

In this work, we first present a comparison of the spectral AOD and derived Angstrom exponent from MODIS with the spectral AOD measured using a sun photometer onboard the oceanographic research vessel (ORV) Sagar Kanya and the derived Angstrom exponent, during its cruise for the ARMEX-II (Arabian Sea Monsoon Experiment) over the South East Arabian Sea (SEAS) in the pre-monsoon season of the year 2003. This initial exercise was carried out with the aim of establishing a quantitative reliability of MODIS aerosol products that are subsequently used for our investigation. Following the method of partial correlation analysis (Spiegel and Stephens, 2000), the daily AOD distribution at $550 \mathrm{~nm}$ from MODIS Level 3 data were used along with NCEP reanalysis fields to study the modulation of AOD by ocean surface winds, convergence of aerosols by winds at different atmospheric altitudes and by hygroscopic growth of aerosols induced by relative humidity (RH).

\section{Data used for the study}

The aerosol observations were conducted onboard the oceanographic research vessel (ORV) Sagar Kanya during its cruise (SK190) over the SEAS for the ARMEX-II under the Indian Climate Research Programme (ICRP). Figure 1 shows the ARMEX-II cruise track. The campaign started on 14 March and ended on 10 April 2003 after covering the oceanic area roughly $7.5^{\circ}-12.5^{\circ} \mathrm{N}$ and $70^{\circ}-77.5^{\circ} \mathrm{E}$. From 23 March to 6 April 2003, the ship remained stationary at a location $9.2^{\circ} \mathrm{N}, 74.5^{\circ} \mathrm{E}$ (hereafter referred to as Time Series Location, TSL) to facilitate time series observation.

Columnar spectral aerosol optical depth (AOD) and size segregated mass concentration of aerosols in the ambient air were measured onboard. Spectral AOD measurements were carried out using a hand held Microtops-II sun photometer (Solar Light Co.) at the wavelengths 380, 500, 675 and $870 \mathrm{~nm}$ (Moorthy et al., 2005). By pointing the instrument manually at the sun, direct spectral solar irradiances were 


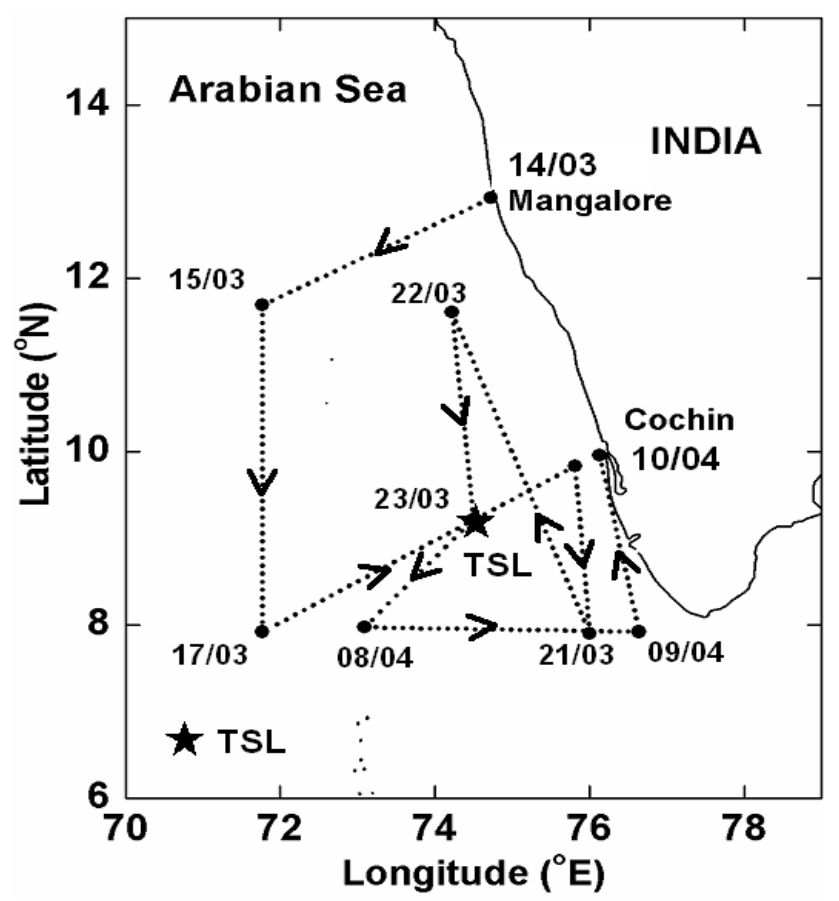

Fig. 1. Cruise track of ORV Sagar Kanya during ARMEX-II (14 March-10 April 2003) over the Arabian Sea. Star denotes the TSL.

measured and converted into AODs using the Lambert-Beer law. A GPS (Global Position System) receiver attached to the instrument provided the coordinates and time of the observation required for the calculations (Morys et al., 2001). In order to minimize the pointing error of the sunphotometer, each measurement consisted of taking four to five readings in quick succession and recording the least among them as the true value (Porter et al., 2001). A strict adherence to this procedure laid down for Microtops measurements (Morys et al., 2001; Porter et al., 2001; Ichoku et al., 2002b) limits the maximum error in the measured AOD to \pm 0.03 . Utmost care was also taken to avoid data collection during cloud interference in the solar viewing direction. During the 28 day long campaign AOD could be measured on 24 days favoured by clear sky condition. The average of the AODs measured on each day was assigned to the $1^{\circ} \times 1^{\circ}$ grid box at the mean position of the ship. Size segregated aerosol mass concentration was measured onboard using a Quartz Crystal Microbalance (QCM) cascade impactor (model PC-2, California measurements Inc.) in 10 size bins with $50 \%$ cut-off diameters at $25,12.5,6.4,3.2,1.6,0.8,0.4,0.2,0.1$ and $0.05 \mu \mathrm{m}$. The flow of ambient air into the instrument was maintained at $240 \mathrm{ml} \mathrm{min}^{-1}$ and the samplings were done at 5-8 min intervals depending on the aerosol loading. The QCM was kept at $10 \mathrm{~m}$ above sea level in the bow of the ship and operated only when RH was less than $78 \%$, in order to preserve the instrument calibration. The operation of QCM was temporarily halted whenever the wind speeds were low (less than $4 \mathrm{~m} / \mathrm{s}$ )

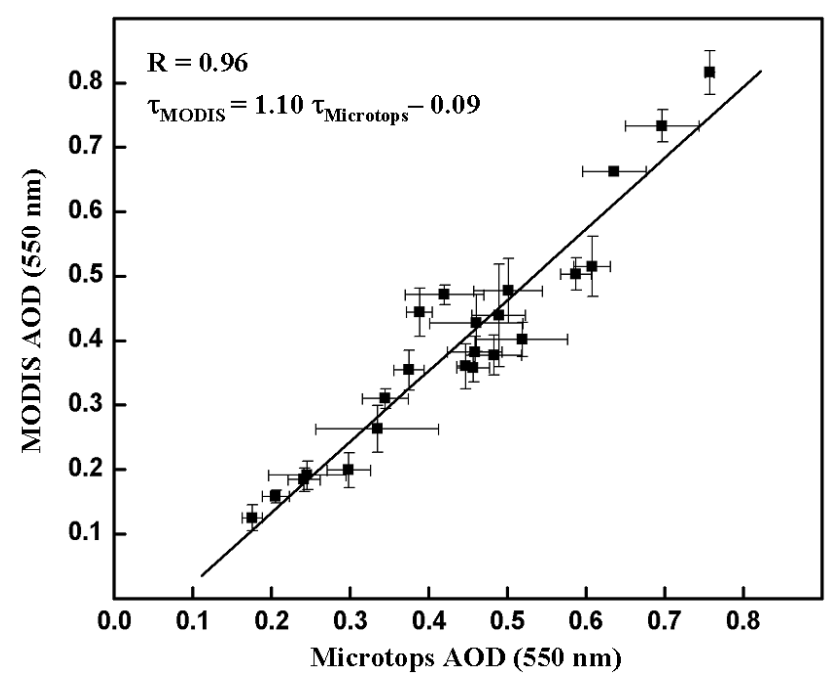

Fig. 2. Scatter plot showing the comparison of MODIS derived daily mean AOD with that from Microtops. Horizontal bars are the standard deviations of the Microtops measurements (at $550 \mathrm{~nm}$ adjusted from $500 \mathrm{~nm}$ ). Vertical bars are the standard deviations of MODIS derived AOD (at $550 \mathrm{~nm}$ ). Correlation coefficient and regression relation are shown in the figure.

Table 1. The correlation coefficients and regression relations of the comparison of MODIS derived AOD with that from Microtops at different wavelengths.

\begin{tabular}{cccc}
\hline $\begin{array}{c}\text { Wavelength } \\
(\mathrm{nm})\end{array}$ & $\begin{array}{c}\text { Correlation } \\
\text { coefficient }(R)\end{array}$ & \multicolumn{2}{c}{$\begin{array}{c}\text { Regression relation } \\
\left(\tau_{\text {MODIS }}=\text { a. } \tau_{\text {Microtops }}+\mathrm{b}\right) \\
a\end{array}$} \\
\hline 550 & 0.96 & 1.10 & -0.09 \\
660 & 0.97 & 1.25 & -0.03 \\
865 & 0.97 & 1.41 & -0.07 \\
\hline
\end{tabular}

with respect to the ship in order to avoid the stagnant particles from the ship's exhaust contaminating the measurements.

The MODIS Level 3 Collection 5 data $\left(1^{\circ} \times 1^{\circ}\right.$ resolution $)$ on spectral AOD, FMF and aerosol mass concentration are used for the present study. Among the seven MODIS spectral channels, only the wavelengths $470 / 550,660$ and $865 \mathrm{~nm}$ match closely with the Microtops wavelengths at 500, 675 and $870 \mathrm{~nm}$, respectively. In order to accomplish a realistic comparison of AODs from the two instruments, the Microtops measured AODs are adjusted to the nearest MODIS wavelengths using the Angstrom exponent derived from Microtops measured AODs at the wavelengths 500, 675 and $870 \mathrm{~nm}$ on the corresponding day through a logarithmic regression. Thus the Microtops measured AOD at $500 \mathrm{~nm}$ is adjusted to $550 \mathrm{~nm}, 675 \mathrm{~nm}$ to $660 \mathrm{~nm}$ and $870 \mathrm{~nm}$ to $865 \mathrm{~nm}$.

MODIS Collection 5 data set is an improvement over Collection 4, generated with upgraded algorithm after extensive 


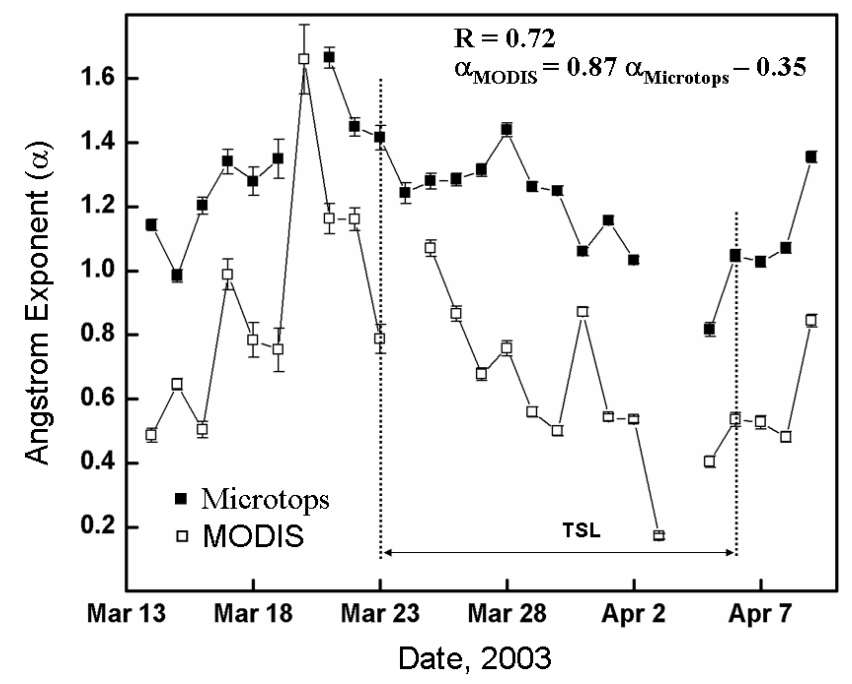

Fig. 3. Time series plot of the daily mean and standard deviation of Angstrom exponent $(\alpha)$ from MODIS derived AODs at 550, 660 and $865 \mathrm{~nm}$ wavelength and those computed from Microtops measured AODs at 500, 675 and $870 \mathrm{~nm}$ wavelengths. The correlation coefficients and the regression relation are also shown in the figure.

validations at different land and ocean sites over the globe (Dubovik et al., 2002; Chu et al., 2003; Ichoku et al., 2003; Levy et al., 2005; Remer et al., 2005). These improvements include incorporation of polarization information in the radiative transfer calculations as well as more realistic aerosol models for different parts of the globe. The Collection 5 data from Aqua and Terra (measured at two different times of the day) are further combined optimally to obtain the daily mean aerosol data needed for our work (Aloysius et al., 2008). This procedure involves averaging the data from the two satellites in every $1^{\circ} \times 1^{\circ}$ pixel if the data from both the satellites are available. In case the data is available only from one satellite in a pixel, that data is retained but if no data is available from either of the satellites, that pixel is left blank.

\section{A comparison of AOD and Angstrom exponent from MODIS with cruise measurements}

Figure 2 depicts the scatter plot of the Microtops measured AOD at $550 \mathrm{~nm}$ (adjusted from $500 \mathrm{~nm}$ as described in Sect. 2) and MODIS retrieved AOD at $550 \mathrm{~nm}$ and the corresponding standard deviations. Here, Microtops values are the average of the measurements and their standard deviation on each day. In the case of MODIS, it is the average of the measurements in the $1^{\circ} \times 1^{\circ}$ boxes covered by the daily trajectory of the ship and the corresponding standard deviation. The mean regression line is also shown in this figure. The correlation and regression coefficients, estimated through regression analysis, are summarized in Table 1 . Following the same procedure, the correlation and regression coefficients

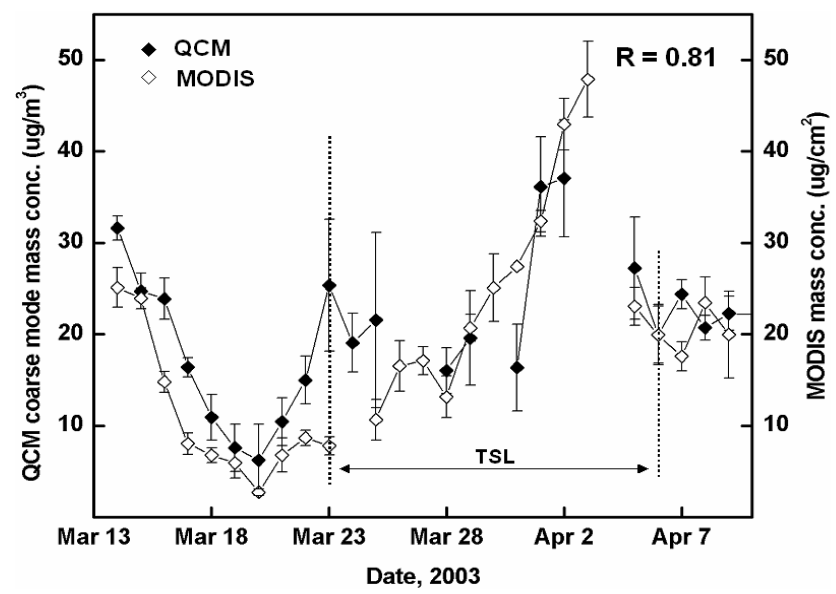

Fig. 4. A comparison of MODIS derived integrated mass concentration with QCM measured coarse mode mass concentration (along with standard deviations) during the ARMEX-II campaign (14 March-10 April 2003) along the cruise track.

at the other two wavelengths are also estimated and included in Table 1. The non-zero intercepts in the regressions result from an improper representation of surface reflectance in the MODIS retrieval procedure while the deviation of the slopes from unity indicates a systematic bias resulting mainly from instrument calibration error and/or an inappropriate choice of the aerosol model in the MODIS retrieval algorithm (Chu et al., 2002; Remer et al., 2005; Tripathi et al., 2005). It should be noted here that the contribution from Microtops errors, being less than 0.03 , could not have given rise to slopes in the regression relations deviating much from unity.

The low scatter of points from the regression line in Fig. 2 as well as the high correlations in Table 1 for the three wavelengths indicate a good agreement of MODIS derived AOD with ship borne measurements. The intercepts, though small (less than 0.1), are always negative, implying a small amount of over correction for the surface reflectance in all the three MODIS spectral channels (Misra et al., 2008). From these regression coefficients we also find that during the campaign, MODIS underestimated in the case of low AOD values but overestimated for high values. The cross over from underestimation to overestimation occurred around $0.9,0.12$ and 0.17 , respectively, for wavelengths 550,660 and $865 \mathrm{~nm}$. For the measured range of AODs, MODIS underestimated at $550 \mathrm{~nm}$ by 0.04 , and overestimated at $660 \mathrm{~nm}$ and $865 \mathrm{~nm}$ by 0.05 and 0.04 , respectively. The increasing slope of the regression towards higher wavelength indicated that the Angstrom exponent derived from MODIS would be smaller than that from Microtops.

Figure 3 shows a time series plot of the mean and the standard deviation of Angstrom exponent $(\alpha)$ determined from MODIS derived AODs at 550, 660 and $865 \mathrm{~nm}$ and those computed from Microtops measured AODs at 500, 675 and $870 \mathrm{~nm}$. One can see that the temporal variations of the two 

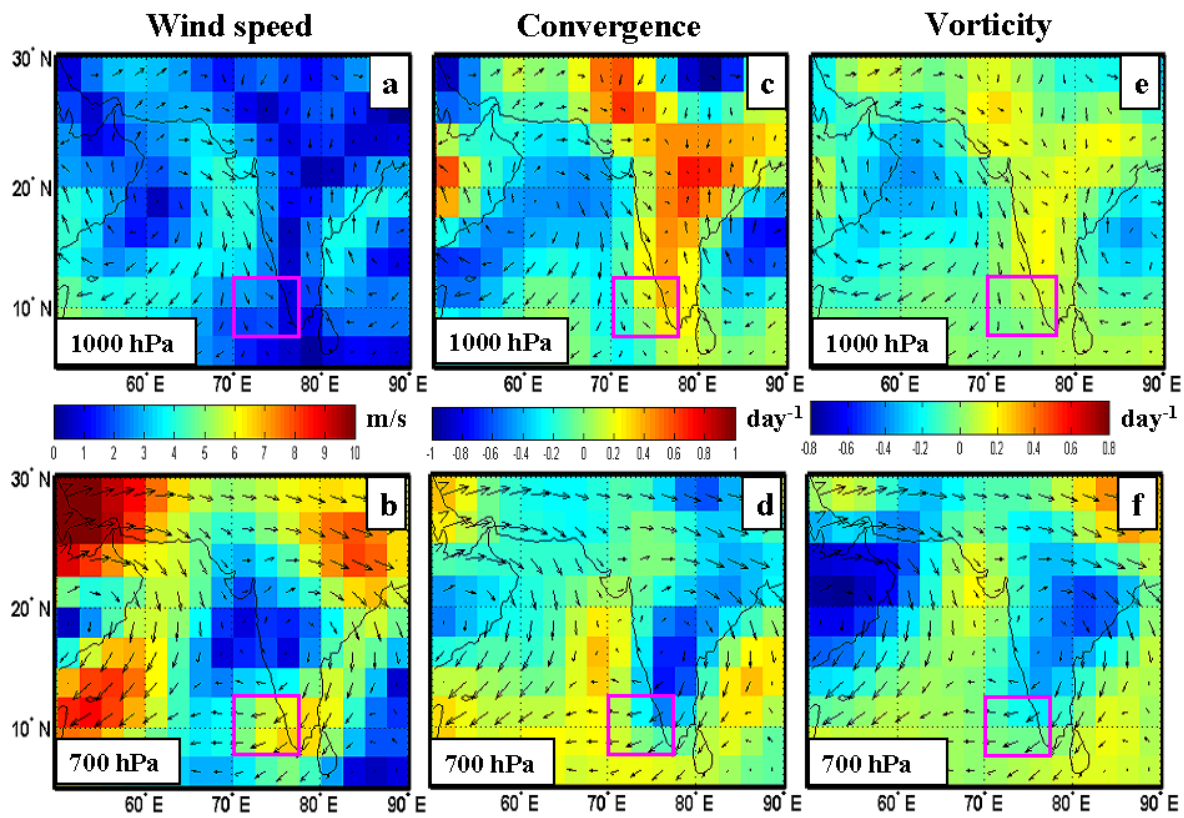

Fig. 5. Average spatial distribution of wind speed at $1000 \mathrm{hPa}(\mathbf{a})$, wind speed at $700 \mathrm{hPa}(\mathbf{b})$, wind convergence at $1000 \mathrm{hPa}(\mathbf{c})$ wind convergence at $700 \mathrm{hPa}(\mathbf{d})$, vorticity at $1000 \mathrm{hPa}(\mathbf{e})$, vorticity at $700 \mathrm{hPa}$ (f) from NCEP reanalysis during ARMEX-II campaign (14 March10 April 2003). The rectangular box shown in the map is the study region.

Angstrom exponents are similar (with a correlation coefficient 0.72 ), but the $\alpha$ from MODIS is always less than that from Microtops by 0.37 on an average.

In order to see whether the above difference in $\alpha$ arose from the differences in the MODIS and Microtops range of wavelengths, an exercise was conducted by changing the wavelengths at the lowest and the highest limits of the Microtops range. We found that an adjustment of AOD at $500 \mathrm{~nm}$ to $550 \mathrm{~nm}$ while keeping the AODs at 675 and $870 \mathrm{~nm}$ unperturbed, decreased $\alpha$ on an average by 0.13 . Similarly, the adjustment of AOD from $870 \mathrm{~nm}$ to $865 \mathrm{~nm}$ while keeping the AODs at 500 and $675 \mathrm{~nm}$ the same, increased the $\alpha$ by 0.01 . This is a consequence of the fact that as the wavelength in the lower limit increases, the Angstrom exponent will shift more and more towards that in the higher wavelength side of the range. In the same way, as the wavelength in the higher limit decreases, the Angstrom exponent will tend more towards that in the lower wavelength side of the range. Thus, if the Microtops wavelength range $(500-870 \mathrm{~nm})$ is made the same as that of MODIS (550-865 nm), the $\alpha$ derived from Microtops would decrease and the difference between the two Angstrom exponents would reduce from 0.37 to 0.25 .

The MODIS data also provides the column integrated mass concentration (in unit $\mu \mathrm{g} / \mathrm{cm}^{2}$ ) derived from the optical depth at $550 \mathrm{~nm}, \mathrm{FMF}$ and modelled extinction coefficients for small and large particles (Remer et al., 2005). The time sequence of MODIS derived mass concentration shows fairly good agreement $(R=0.81)$ with that of the coarse mode component (particle diameter in the range 1.6 to $25 \mu \mathrm{m}$ ) of sur- face level aerosol mass concentration (in unit $\mu \mathrm{g} / \mathrm{m}^{3}$ ) measured using QCM on the ship (Fig. 4). This indicates that the variations in column integrated mass concentration over the ARMEX-II domain resulted mainly from the changes in the surface level coarse mode mass concentration.

\section{Meteorological conditions and aerosol distribution over the campaign domain}

Over the land, winds blowing over loose, dry soil raise particles into the air while over the ocean, they excite surface waves which in the breaking phase release copious amounts of marine aerosols into the atmosphere (Blanchard and Woodcock, 1980; Jaenicke, 1980; Prospero, 1983). Besides providing a means for long range transport, winds can also influence the spatial distribution of aerosols by accumulation through horizontal convergence $\left[-\left(\partial v_{x} / \partial x+\partial v_{y} / \partial y\right)\right]$. Atmospheric winds, being mainly governed by pressure gradients, are in turn related to the winds themselves through vorticity $\left(\partial v_{y} / \partial x-\partial v_{x} / \partial y\right)$ (negative vorticity corresponding to high pressure and vice versa). Thus, wind speed, convergence and vorticity are three important variables governing the generation, transport and dispersal of aerosols.

The mean NCEP wind, wind convergence and vorticity at two altitudes $-1000 \mathrm{hPa}$ and $700 \mathrm{hPa}$ in the geographical region $50^{\circ}-90^{\circ} \mathrm{E}$ longitude over the latitude region $5^{\circ}-30^{\circ} \mathrm{N}$ during the campaign period are presented in Fig. 5. Note that, at the $1000 \mathrm{hPa}$ level, a high pressure system (indicated by large negative vorticity in Fig. 5e) prevails in the north 


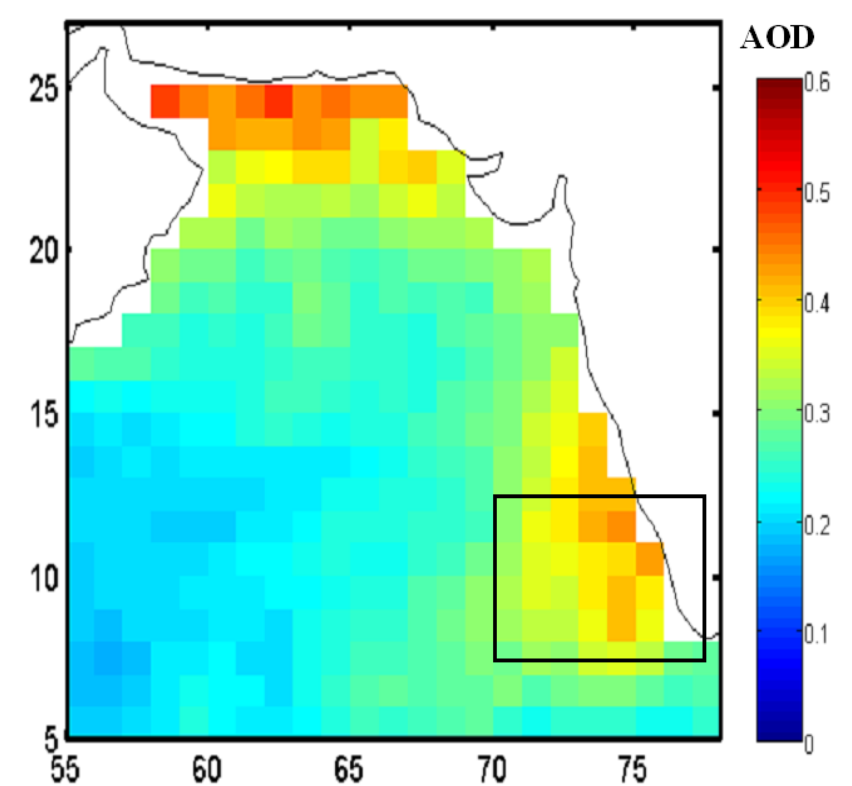

Fig. 6. Mean spatial distribution of daily AOD from MODIS over the Arabian Sea during the ARMEX-II campaign (14 March-10 April 2003). The rectangular region marked by the black box is the study domain.

western quarter of the Arabian Sea leading to an anticyclonic flow from the Arabian desert. Attracted by the low pressure over the Indian peninsula (indicated by a slight positive vorticity in Fig. 5e), this flow speeds up after traversing through the Northern Arabian Sea and turns southward along the west coast and decelerates subsequently as it reaches the southern tip of the Indian Peninsula. At the south western quarter of the Indian landmass (Fig. 5c), a fairly strong convergence intrudes into the ARMEX-II domain across the west coast of the Indian peninsula.

At higher altitude $(700 \mathrm{hPa}$ level), winds in general are relatively stronger. The westerly winds from Arabia (at latitudes around $23^{\circ}-27^{\circ} \mathrm{N}$ ), turns southward in the midArabian sea (Fig. 5b) without reaching SEAS. But, after a long eastward flow, the winds from latitudes beyond $27^{\circ} \mathrm{N}$ turn southward near eastern India and sweep over the western Bay of Bengal to reach SEAS from the north east. At the higher altitude, the anticyclone over the North Western Arabian Sea has moved westward over to the Arabian land mass and the anticyclone over the Bay of Bengal (at the lower level) has shifted to the Indian peninsula. The wind convergence nearly covering the entire Indian landmass in the lower altitude is replaced by a divergence at the higher altitude (Fig. 5d).

Figure 6 shows the mean spatial distribution of AOD over the Arabian Sea for the campaign period (14 March-10 April 2003) obtained from daily MODIS Level 3 data (Terra and Aqua combined). Over the Arabian Sea, high values of AOD are observable over the northern/north western parts and

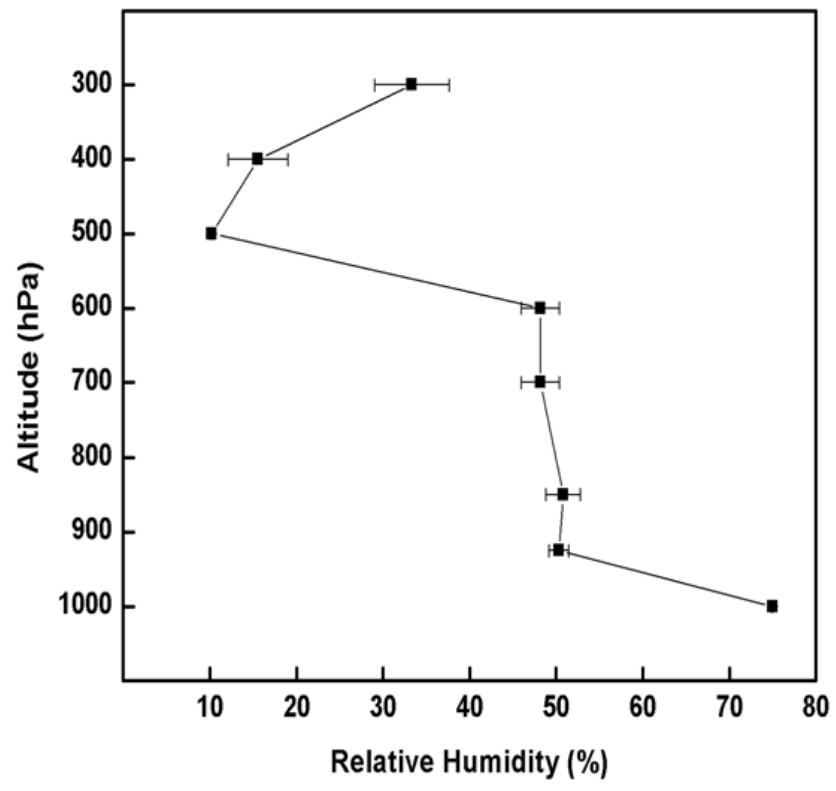

Fig. 7. Mean relative humidity from NCEP at different atmospheric altitudes during the ARMEX-II Campaign (14 March-10 April 2003), over the study region.

SEAS. The high AOD in the North/North Western Arabian Sea is mainly caused by the dust transported from the adjacent arid regions where, even at low speeds (below $4 \mathrm{~m} / \mathrm{s}$ ), winds have the proper direction for such a transport. On the other hand, the increased AOD in SEAS could be attributed to aerosol accumulation through wind convergence at lower altitude (Fig. 5c). From the wind pattern, the origin of these aerosols can be traced back to arid regions of Arabia. Besides, wind induced sea salt aerosols and anthropogenic aerosols from the Indian west coast might also contribute to the high AOD here. In the higher altitude, we also see a possibility of aerosol advection from the continental regions of North Western and Central India, Indo Gangetic plane and Indian east coast (Fig. 5b). However, the contributions from these regions to the total aerosol loading could only be marginal because of the wind divergence in the higher altitudes over the SEAS (Fig. 5d), which favours the dispersion of aerosols rather than accumulation. Earlier studies by Moorthy et al. (2005) using HYSPLIT (Hybrid Single Particle Lagrangian Integrated Trajectory) back trajectories have indicated that the aerosols over the ARMEX site in the lower atmospheric levels (500 to $1800 \mathrm{~m}$ ) were transported directly from west Asian regions, western India and the west coast of India while the aerosols in the higher atmospheric levels (above $1800 \mathrm{~m}$ ) were brought by air parcels from North West India, central India and Bay of Bengal in long winding trajectories spending 4 to 7 days, thereby reducing the particle concentrations to low levels.

Note that, AOD can also be affected by changes in relative humidity (RH) through growth/contraction of hygroscopic 


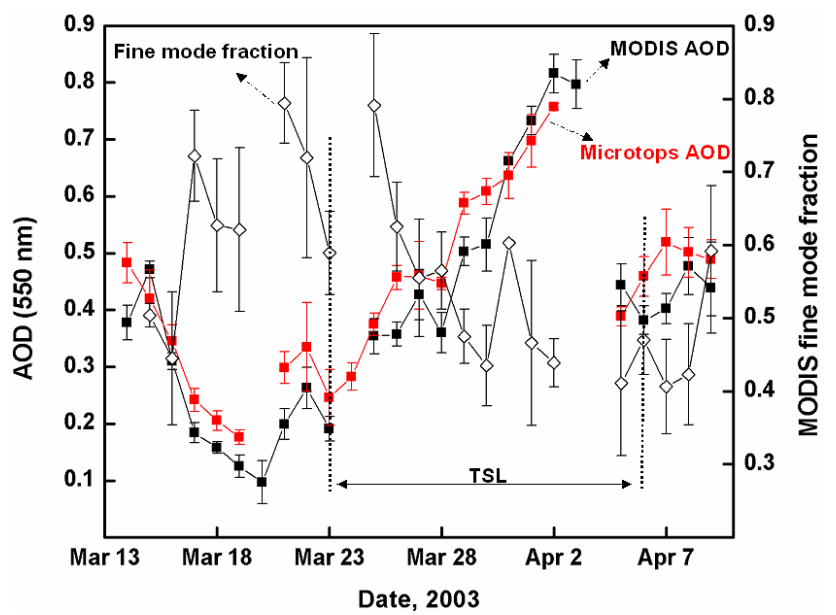

Fig. 8. Time series plot of AOD from Microtops and MODIS along with fine mode fraction from MODIS (along with the standard deviations) during the ARMEX-II campaign (14 March-10 April 2003) along the cruise track.

particles. But this process is important only for $\mathrm{RH}$ above around 70\% (Parameswaran, 1998). Figure 7 shows the mean NCEP vertical profile of RH over the study region during the campaign. Here we see that except for the lowest altitude where the value of RH marginally exceeds $70 \%$, the values are generally less than $50 \%$. Thus, over the study region hygroscopic growth of aerosols could have been a significant factor only at very low altitude during the campaign period.

\section{Temporal characteristics of AOD during ARMEX-II}

The MODIS observed and Microtops derived AODs at $550 \mathrm{~nm}$ and FMF from MODIS at the ship's location (along the cruise track), is shown in Fig. 8. It can be seen that, in general, the temporal variation of FMF is in the opposite phase with that of AOD and also in near agreement with that of $\alpha$ presented in Fig. 3 .

A detailed analysis of the spatial map of AOD from MODIS over the Arabian Sea reveals that most of the prominent variations observed on the ship resulted from the southward migration of pockets of aerosols along the Indian west coast. This movement of aerosol pockets as observed by MODIS at different phases of variation in AOD seen on the ship on a few selected days is presented in Fig. 9 along with the location of the ship.

The high AOD at the start of the cruise on 14 March from Mangalore was due to the presence of a weak aerosol pocket in the region where the ship was located (Fig. 9a). This pocket subsequently shifted southward and dispersed within 4-5 days. Associated with this, the AOD over the ship decreased and continued to remain low until 20 March except for some minor fluctuations (Fig. 8). By this time,

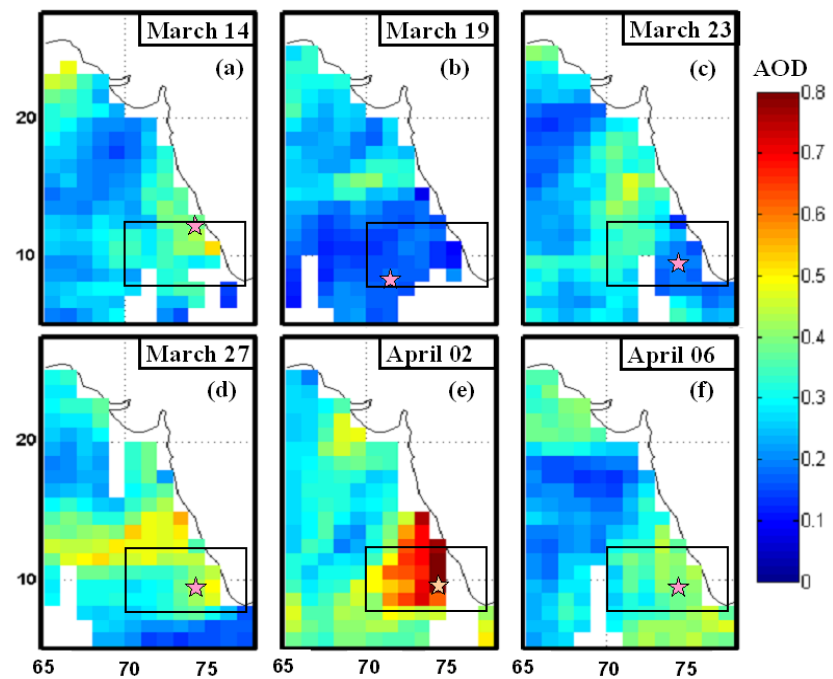

Fig. 9. Spatial distribution of AOD from MODIS over the Arabian Sea on 14 March (a), 19 March (b), 23 March (c), 27 March (d), 2 April (e), 6 April (f) depicting the southward movement of aerosol pockets during ARMEX-II campaign (14 March-10 April 2003). Star denotes the position of ORV Sagar Kanya on the respective dates.

another pocket of aerosols had started its southward movement from the north. As this pocket approached the ship (positioned at TSL), the AOD over the ship started increasing from 23 March (Fig. 9c). With the advance of days, the southward drifting aerosol pocket also intensified consequent to a short term strengthening and the eastward intrusion of the high pressure system in the North Western Arabian Sea supported by the convergence over the SEAS (Fig. 9d). This aerosol pocket, after acquiring peak intensity on 2 April (AOD greater than 0.8), moved on and dissipated at the southern tip of the Indian peninsula (Fig. 9e and f) as the high pressure system weakened. By the end of the TSL period (6 April), AOD over the ship decreased to normal values. Thus the southward movement of the aerosol pocket matched well with the episodic event of AOD enhancement and the decay as observed onboard the ship.

A striking feature in Fig. 8 is the high values of AOD nearly synchronising with the low values of FMF and the Angstrom exponent (Fig. 3) during the episodic event. This is possible only if the particles constituting the aerosol plume were predominantly of a coarse mode probably, mineral dust originated from the arid regions of Arabia or sea salt aerosols produced in the high wind regime near the north western coast of India. However, considering the sea surface wind speed near the Indian coast and wind speed dependence of sea salt production reported by various authors (Blanchard and Woodcock, 1980; Moorthy and Satheesh, 2000; Smirnov et al., 2003; Satheesh et al., 2006), such a high value of AOD could not be caused by these winds by themselves indicating the possibility of mineral dust dominating the aerosol pocket. 


\section{Modulation of daily AOD variations by circulation variables and $\mathbf{R H}$}

Motivated by the above observations, which pointed to a close association between wind field and AOD variations, a detailed investigation is carried out to establish the role of different circulation parameters (wind speed and convergence) and RH on the observed modulation over the oceanic region of present interest. For this we utilized the Level 3 daily AOD values at $550 \mathrm{~nm}$ from MODIS $\left(1^{\circ} \times 1^{\circ}\right.$ resolution) and NCEP and $\mathrm{RH}$ reanalysis $\left(2.5^{\circ} \times 2.5^{\circ}\right.$ resolution). The four atmospheric parameters considered are:

\subsection{Change in the AOD per day}

$V_{1}=\tau_{2}-\tau_{1}$

where $\tau_{2}$ corresponds to AOD in each pixel of the domain on a given day and $\tau_{1}$ that in the same pixel on the previous day. In a pair of successive days, only those pixels with data available on both the days were considered.

\subsection{Horizontal surface $(1000 \mathrm{hPa})$ wind speed}

$V_{2}=\sqrt{\left\{\left[v_{x}(1000 \mathrm{hPa})\right]^{2}+\left[v_{y}(1000 \mathrm{hPa})\right]^{2}\right\}}$

where $v_{x}$ and $v_{y}$ refer to meridional and zonal components of vector wind.

\subsection{Column integrated horizontal aerosol flux conver- gence}

The accumulation effect of wind convergence is expressed through a more appropriate physical quantity - the convergence of aerosol flux which is the product of aerosol concentration and wind. This combination is selected since any change in aerosol concentration at a given location is governed not merely by the convergence of winds but also by the aerosol concentration through the continuity relation (Aloysius et al., 2008). This quantity is defined by

$V_{3}=-\int_{0}^{Z}\left\{\frac{\partial}{\partial x}\left[\rho(z) v_{x}(z)\right]+\frac{\partial}{\partial y}\left[\rho(z) v_{y}(z)\right]\right\} d z$

where $z$ corresponds to altitude and $Z$ is the upper limit of integration (equivalent to $400 \mathrm{hPa}$ here). $\rho$ is the aerosol extinction coefficient (a measure of aerosol concentration) related to MODIS derived $\operatorname{AOD}(\tau)$ as

$\rho(z)=\frac{\tau}{L} \exp \left(-\frac{z}{L}\right)$

where $L$ is the aerosol scale height which corresponds to its vertical spread. By controlling $L$, one can change the weight given to winds at different altitudes in the aerosol flux. In this study, we have considered scale heights $0.5,1,2,3$ and $4 \mathrm{~km}$.

\subsection{Relative humidity}

The quantity RH is considered at $1000 \mathrm{hPa}$ alone since its value was greater than $70 \%$ only at this level over the study domain (Fig. 7). We define,

$$
V_{4}=\mathrm{RH} \text { at } 1000 \mathrm{hPa}
$$

Using the above four variables we have estimated the partial correlation of $V_{1}$ with $V_{2}, V_{3}$ and $V_{4}$, treating $V_{1}$ as the dependent and the other three as independent variables. The method of partial correlation analysis aims to estimate the strength of the relationship between the dependent variable and an independent variable by minimizing the interferences from the other independent variables.

In the case of one dependent variable $V_{a}$ and three independent variables $V_{b}, V_{c}$ and $V_{d}$, partial correlation between $V_{a}$ and $V_{b}$ is defined by (Spiegel and Stephens, 2000; Gupta 2005),

$R_{a b . c d}=\frac{R_{a b . d}-R_{a c . d} \cdot R_{b c . d}}{\sqrt{\left(1-R_{a c . d}^{2}\right)\left(1-R_{b c . d}^{2}\right)}}$

where each $R_{l m . n}$ is expressed in terms of the respective cross correlation as

$R_{l m . n}=\frac{R_{l m}-R_{l n} R_{m n}}{\sqrt{\left(1-R_{\ln }^{2}\right)\left(1-R_{m n}^{2}\right)}}$

Since the NCEP reanalysis variables are available only at $2.5^{\circ} \times 2.5^{\circ}$ resolution, the AOD data from MODIS is also degraded to this resolution. This is done with the criterion that in each $2.5^{\circ} \times 2.5^{\circ}$ grid, AOD has to be available for a minimum of $60 \%$ of its portion. Otherwise, the grid is kept blank (Aloysius et al., 2008). In the computation of $V_{3}$, the spatial step sizes in the $\mathrm{x}$ - and $\mathrm{y}$-directions are corrected for the earth's curvature. Details of aerosol flux convergence calculation incorporating the AOD from MODIS (taking care of blank pixels) and the NCEP wind field as well as the vertical integration using a standard Lagrangian scheme (Jain et al., 1993), are described in Aloysius et al. (2008). The quantities $V_{1}, V_{2}, V_{3}$ and $V_{4}$ are averaged for each day of the campaign period (except for the first day for which $V_{1}$ was not defined) over the study domain, excluding the land and coastal pixels, because of the fact that as the MODIS employs different retrieval schemes over land and ocean (Kaufman et al., 1997; Remer et al., 2005; Levy et al., 2007), any discontinuity in AOD across the land-ocean boundary would introduce errors in the flux gradient computation. Since the physical mechanisms represented by $V_{2}, V_{3}$ and $V_{4}$ responsible for the AOD change from one day to the next $\left(V_{1}\right)$ act on both the days in a continuous manner, these three quantities are further averaged over the two days. 
Table 2. Variation of partial correlation coefficients $R_{12.34}, R_{13.24}$ and $R_{14.23}$ computed for different aerosols scale heights during the TSL period over the study domain.

\begin{tabular}{cccc}
\hline $\begin{array}{c}\text { Scale height } \\
L(\mathrm{~km})\end{array}$ & $\begin{array}{c}\text { Partial correlation } \\
\text { with surface wind } \\
R_{12.34}\end{array}$ & $\begin{array}{c}\text { Partial correlation } \\
\text { with convergence } \\
R_{13.24}\end{array}$ & $\begin{array}{c}\text { Partial correlation } \\
\text { with RH } \\
R_{14.23}\end{array}$ \\
\hline 0.5 & $<0.1$ & 0.55 & 0.27 \\
1 & $<0.1$ & 0.69 & 0.52 \\
2 & $<0.1$ & 0.64 & 0.48 \\
3 & $<0.1$ & 0.49 & 0.28 \\
4 & $<0.1$ & 0.42 & 0.21 \\
\hline
\end{tabular}

\section{Results and discussions}

When the partial correlations of $V_{1}$ with $V_{2}, V_{3}$ and $V_{4}$ (i.e., $R_{12.34}, R_{13.24}$ and $R_{14.23}$, respectively) are computed for the entire campaign period, only a weak influence of flux convergence $\left(V_{3}\right)$ on AOD modulation $\left(V_{1}\right)$ (maximum of $R_{13.24}$, about 0.25 ) is found, while the influence of the other two parameters are negligible (both $R_{12.34}$ and $R_{14.23}$, below 0.05 ). But when the analysis is restricted to the TSL period in which the episodic event took place, both $V_{3}$ and $V_{4}$ are found to exert a substantial influence on AOD modulation. The estimated partial correlations for different values of $L$ are presented in Table 2.

Among the three partial correlations, $R_{13.24}$ and $R_{14.23}$ are significant while $R_{12.34}$ is totally negligible. With an increase in scale height $(L)$, both $R_{13.24}$ and $R_{14.23}$ increase initially, attain a maximum for $L=1 \mathrm{~km}$ and decrease slowly thereafter. As stated in Sect. 6, larger $L$ corresponds to increased significance of upper level winds in the flux convergence computation.

The initial increase of $R_{13.24}$ with $L$ indicates that convergence in winds close to the surface is inadequate in modulating AOD. At the same time, the decrease of $R_{13.24}$ for $L$ greater than $1 \mathrm{~km}$ means that greater weight of higher altitude winds (through convergence) is also unimportant. Therefore, an optimum weight for lower as well as higher level atmospheric winds corresponding to the scale height around $1 \mathrm{~km}$ provides maximum effect for flux convergence on AOD modulation. Figure 10 depicts the time series of AOD change per day and flux convergence over the domain for $L=1 \mathrm{~km}$ which shows a fairly good correspondence between the two during the episodic event in the TSL period.

The above inference is also supported by the mean vertical wind field over the study domain shown in Fig. 11. A change over from updraft at surface level to downdraft observable at levels above $925 \mathrm{hPa}$ could be supporting the confinement of aerosols up to heights below around $1 \mathrm{~km}$.

The partial correlation $R_{14.23}$ also shows an increase as $L$ is increased from 0.5 to $1 \mathrm{~km}$ followed by a decrease similar to the case for $R_{13.24}$ (Table 2). This is because the inter-

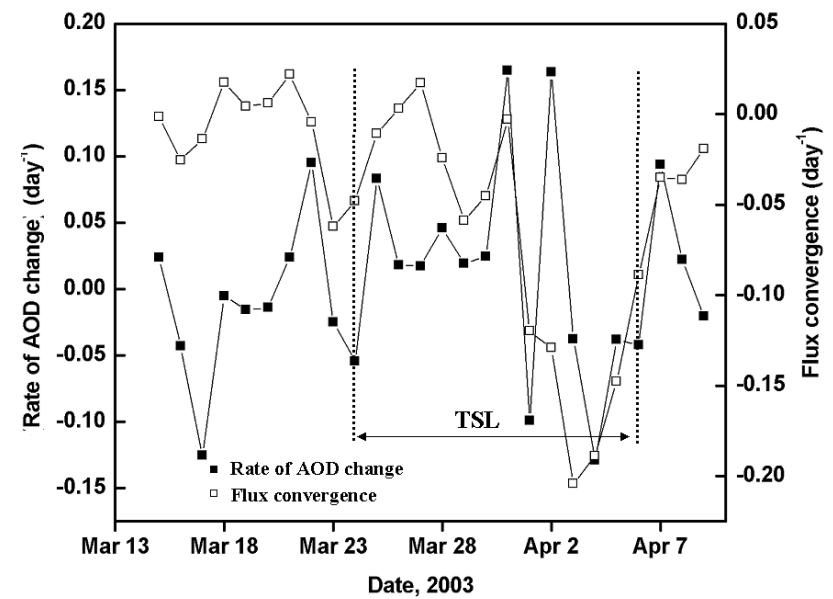

Fig. 10. Time series plot showing the AOD rate of change per day along with the flux convergence averaged for the study domain, during ARMEX-II (14 March-10 April 2003).

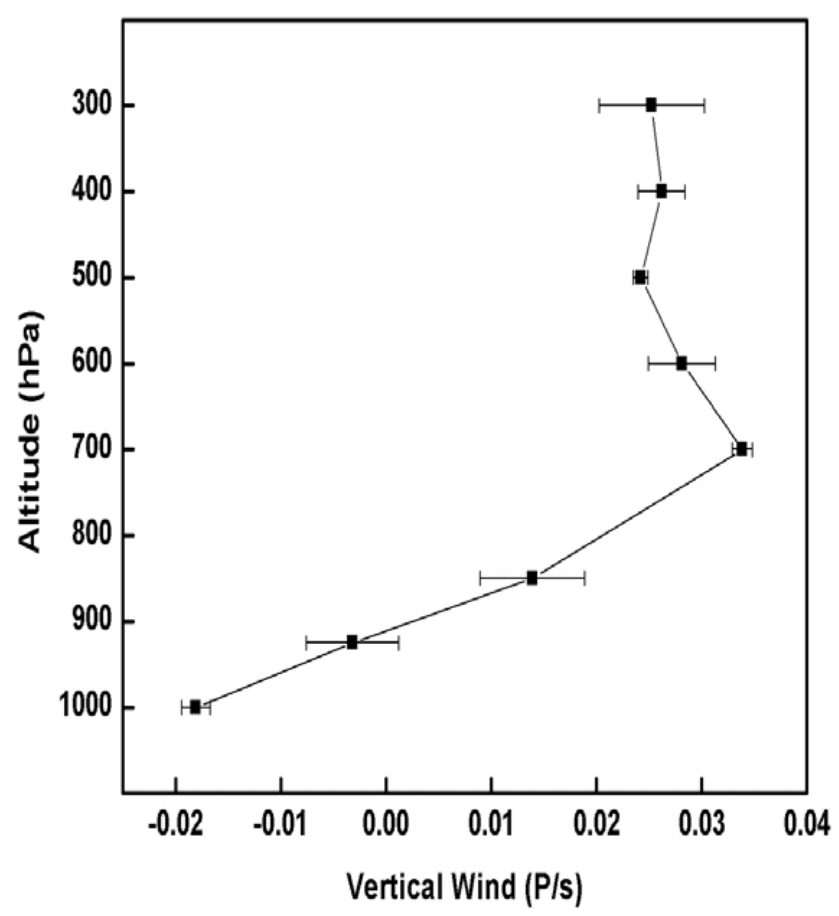

Fig. 11. Mean vertical wind from NCEP at different atmospheric altitudes (along with standard deviation) during TSL period (23 March-6 April 2003), over the study domain.

ference from flux convergence on the partial correlation of AOD modulation with $\mathrm{RH}$ reduces as $L$ increases from 0.5 to $1 \mathrm{~km}$ and increases thereafter. Thus, the relationship between AOD modulation and flux convergence, as well as that between AOD modulation and RH, are the best corresponding to the case $L=1 \mathrm{~km}$.

Though the low value of $R_{12.34}$ (Table 2) reflects no influence of local surface wind on AOD modulation, the moderate 
correlation with RH indicates the presence of wind generated hygroscopic aerosols. In Fig. 5a, a region of comparitively higher surface winds is observable in the upwind north/north west direction of the study domain. In this region, wind attained its maximum speed of 6-7 m/s during TSL period. We have investigated the possibility of wind generated marine aerosols being transported from this region to the study domain in the downwind direction. Considering a zone $12.5^{\circ}$ $20^{\circ} \mathrm{N}$ and $67.5^{\circ}-75^{\circ} \mathrm{E}$ over this high wind region, computation of correlation between the surface winds at this place and the AOD over the study domain with different time delays yielded a maximum correlation of 0.66 for a time delay of two days. With the average wind speed of $4.5 \mathrm{~m} / \mathrm{s}$ found over the high wind zone during the TSL period, the time required for the aerosols to reach from here to the ARMEX-II domain turns out to be around two days. This points to the possibility of non-negligible presence of wind generated hygroscopic marine aerosols over the ARMEX-II domain transported from the upwind direction.

\section{Summary and conclusions}

A comparison of MODIS derived spectral AOD with the Microtops measurements over South East Arabian Sea shows good agreement with correlation coefficients $0.96-0.97$ with mean deviations around 0.04 while the Angstrom exponents derived from their spectral AODs agree with a correlation 0.72 .

The studies on the spatial AOD distribution from MODIS during ARMEX-II reveals that the episodic enhancement and decay of AOD observed over the study region, during the TSL period (23 March to 6 April 2003), was caused by the southward migration of an intensifying aerosol pocket along the Indian west coast driven by a short term enhancement and weakening of the pressure system in the North Western Arabian Sea and the low altitude convergence over SEAS. The decrease of Angstrom Exponent and fine mode fraction coinciding with this event reveals that this aerosol plume was mainly composed of coarse mode particles. The prevailing wind system during the campaign period over India and surrounding oceans, shows a strong possibility for the transport of mineral dust from the dry regions of Arabia by the lower altitude winds which converge over SEAS. At the same time such a transport seems unlikely at higher altitudes because of the long distance winds have to travel and the upper level divergence.

The influence of circulation variables (wind convergence and surface wind speed) and relative humidity on the dayto-day AOD variations over the ARMEX-II domain is further investigated using NCEP reanalysis fields and MODIS data. A partial correlation analysis is adopted to examine the influence of each of these parameters (aerosol flux convergence, surface wind speed and surface RH considered as the independent variables) on AOD variations (considered as the dependent variable). When the data of the entire period is used for this analysis, none of the independent variables are found to exert any significant influence on AOD modulation. However, when the exercise is confined to the TSL period (23 March to 6 April 2003) during which the episodic growth and decay of AOD had taken place, the AOD modulation is found to be significantly influenced by flux convergence at low altitudes (partial correlation 0.69). During this period RH also indicates some influence on AOD modulation (partial correlation 0.52) though not as strong as that of flux convergence, but surface winds do not show any substantial effect.

Even though the local surface winds are found ineffective, the winds over a region in the upwind direction from the study domain are found to correlate well $(R=0.66)$ with the AOD over the domain with a lag of two days. This observation, along with the moderate partial correlation of AOD with RH over the study domain, points to a non-negligible contribution of wind generated hygroscopic marine aerosols from the upwind area to the total aerosol load over the ARMEX-II domain during the TSL period. However, as the wind speeds were rather moderate (maximum around $7 \mathrm{~m} / \mathrm{s}$ ), wind generated marine aerosols, could not have contributed substantially to the high optical depth over the study domain.

The above facts, together with the close correspondence between MODIS column mass concentration and the QCM measured coarse mode mass concentration onboard the ship, suggest that the aerosol plume, encountered during the TSL period, was mostly composed of coarse mode mineral dust particles confined to the lower altitudes of the atmosphere transported from the arid regions of Arabia.

Acknowledgements. This study was carried out as a part of ISROGeosphere Biosphere Programme. We acknowledge NASA for providing MODIS aerosol data through their website ftp://ladsftp. nascom.nasa.gov. We are grateful to NOAA-CDC for the reanalysis data provided through their website http://www.cdc.noaa.gov. Presently, K. Parameswaran is Emeritus Scientist, CSIR. Our sincere thanks also to the referee for his useful suggestions, which has helped in improving the paper.

Topical Editor F. D'Andrea thanks one anonymous referee for her/his help in evaluating this paper.

\section{References}

Albrecht, B. A.: Aerosols, cloud microphysics and fractional cloudiness, Science, 245, 1227-1230, 1989.

Aloysius, M., Mohan, M., Parameswaran, K., George, S. K., and Nair, P. R.: Aerosol transport over the Gangetic basin during ISRO-GBP land campaign-II, Ann. Geophys., 26, 431-440, 2008, http://www.ann-geophys.net/26/431/2008/.

Andreae, M. O.: Climatic effects of changing atmospheric levels, World survey of climatology, edited by: Henderson Sellers, A., Future climates of the world, vol. 16, Elseiver, 341-392,1995.

Bates, T. S., Huebert, B. J., Gras, J. L., Griffiths, F. B., and Durkee, P. A.: International Global Atmospheric Chemistry (IGAC) Project's first Aerosol Characterisation Experiment (ACE 1): Overview, J. Geophys. Res., 103, 16297-16318, 1998. 
Blanchard, D. C. and Woodcock, A. H.: The production concentration and vertical distribution of the sea salt aerosols, Ann. N. Y. Acad. Sci., 338, 330-347, 1980.

Boucher, O., Schwartz, S. E., Ackerman, T. P., Anderson, T. L., et al.: Intercomparison of models representing direct shortwave radiative forcing by sulfate aerosols, J. Geophys. Res., 103, 1697916988, 1998.

Charlson, R. J., Schwartz, S. E., Hales, J. M., Cess, R. D., Coakley Jr., J. A., Hansen, J. E., and Hofmann, D. J.: Climate forcing by anthropogenic aerosols, Science, 255, 423-430, 1992.

Chu, D. A., Kaufman, Y. J., Ichoku, C., Remer, L. A., Tanre, D., and Holben, B. N.: Validation of MODIS aerosol optical depth retrieval over land, Geophys. Res. Lett., 29(12), MOD2, doi:10.1029/2001GL013205, 2002.

Chu, D. A., Kaufman, Y. J., Zibordi, G., Chern, J. D., Mao, J., Li, C., and Holben, B. N.: Global monitoring of air pollution over land from the Earth Observing System - Terra Moderate Resolution Imaging Spectroradiometer (MODIS), J. Geophys. Res., 108(D21), 4661, doi:10.1029/2002JD003179, 2003.

Coakley, J. A., Cess, R. D., and Yurevich, F. B.: The effect of tropospheric aerosols on the earth's radiation budget: A parametrisation for climte models, J. Atmos. Sci., 40, 116-138, 1983.

Dubovik, O., Holben, B. N., Eck, T. F., Smirnov, A., Kaufman, Y. J., King, M. D., King, M. D., Tanre, D., and Slutsker, I.: Variability of absorption and optical properties of key aerosol types observed in world wide locations, J. Atmos. Sci., 59, 590-608, 2002.

Gupta, S. P.: Statistical methods, Sultan Chand and Sons, Educational publishers, New Delhi, 1110-1118 pp, 2005.

Hansen, J., Sato, M., and Ruedy, R.: Radiative forcing and climate response, J. Geophys. Res., 102, 6831-6864, 1997.

Haywood, J. and Boucher, O.: Estimates of the direct and indirect radiative forcing due to tropospheric aerosols: a review, Rev. Geophys., 38(4), 513-543, 2000.

Holben, B. N., Eck, T. F., Slutsker, I., Tanre, D., Buis, J. P., Setzer, A., Vermote, E., Reagan, J. A., Kaufman, Y. J., Nakajima, T., Lavenu, F., Jankowiak, I., and Smirnov, A.: AERONET - A federated instrument network and data archive for aerosol characterisation, Remote Sens. Environ., 66, 1-16, 1998.

Ichoku, C., Chu, D. A., Mattoo, S., Kaufman, Y. J., Remer, L. A., Tanre, D., Slutsker, I., and Holben, B.: A Spatio-temporal approach for global validation and analysis of MODIS aerosol products, Geophys. Res. Lett., 29, MOD1, doi:10.1029/2001GL013206, 2002a.

Ichoku, C., Levy, R., Kaufman, Y. J., Remer, L. A., Li, R.-R., Martins, J. V., Holben, B. N., Abuhassan, N., Slutsker, I., Eck, T. F., and Pietras, C.: Analysis of the performance characteristics of the five-channel Microtops II Sun photometer for measuring aerosol optical thickness and precipitable water vapour, J. Geophys. Res., 107, D13, doi:10.1029/2001JD001302, 2002b.

Ichoku, C., Remer, L. A., Kaufman, Y. J., Levy, R., Chu, D. A., Tanre, D., and Holben, B. N.: MODIS observation of aerosols and estimation of aerosol radiative forcing over southern Africa during SAFARI 2000, J. Geophys. Res., 108, 8499, doi:1029/2002JD002366, 2003.

Intergovernmental Panel on Climate Change (IPCC): Climate change 2001: The Scientific Basis, edited by: Houghton, J. T., Ding, Y., Griggs, D. J., Nouger, M., et al., Cambridge Univ. Press, New York, 896 pp., 2001.
Jaenicke, R.: Natural aerosols, Annuals of the New York Academy of Science, 317-329, 1980.

Jain, M. K., Iyengar, S. R. K., and Jain, R. K.: Numerical methods for scientific and engineering computation, Wiley Eastern Limited, 249-251, 1993.

Jayaraman, A. S., Satheesh, S. K., Mitra, A. P., and Ramnathan, V.: Latitude gradient in aerosol properties across the Inter Tropical Convergence Zone: Results from joint Indo-U.S study onboard Sager Kanya, Curr. Sci., 80, 128-137, 2001.

Jennings, S. G. and O'Dowd, C. D.: Volatitlity of aerosol at Mace Head on the west coast of Ireland, J. Geophys. Res., 95, 1393713948, 1990.

Jones, T. A. and Christopher, S. A.: MODIS derived fine mode fraction characteristics of marine, dust, and anthropogenic aerosols over the ocean, constrained by GOCART, MOPITT, and TOMS, J. Geophys. Res., 112, D22204, doi:10.1029/2007JD008974, 2007.

Kaufman, Y. J., Tanre, D., Gordon, H. R., Nakajima, T., Lenoble, J., Frouin, R., Grassl, H., Herman, B. M., King, M. D., and Teillet, P. M.: Passive remote sensing of tropospheric aerosol and atmospheric correction for the aerosol effect, J. Geophys. Res., 102(D14), 16815-16830, 1997a.

Kaufman, Y. J., Tanre, D., Remer, L. A., Vermote, E. F., Chu, A., and Holben, B. N.: Operational remote sensing of tropospheric aerosol over land from EOS moderate resolution imaging spectroradiometer, J. Geophys. Res., 102, 17051-17068, 1997 b.

Kaufman, Y. J., Holben, B. N., Tanre, D., Slutsker, I., Smirnov, A., and Eck, T. F.: Will aerosol measurements from Terra and Aqua polar orbiting satellites represent daily aerosol abundance and properties?, Geophys. Res. Lett., 27, 3861-3864, 2000.

Kaufman, Y. J., Tanre, D., and Boucher, O.: A satellite view of aerosols in climate system, Nature, 419, 215-223, 2002.

King, M. D., Kaufman, Y. J., Tanre, D., and Nakajima, T.: Remote sensing of Tropospheric Aerosols from Space: Past, Present, and Future, B. Am. Meteorol. Soc., 80, 2229-2259, 1999.

Krishnamurthy, T. N., Jha, B., Prospero, J. M., Jayaraman, A., and Ramanathan, V.: Aerosol and pollutant transport over the tropical Indian Ocean during the January-Febrauary, 1996 pre-INDOEX cruise, Tellus, Ser. B, 50, 521-542, 1998.

Levy, R. C., Remer, L. A., Martins, J. V., Kaufman, Y. J., PlanaFattori, A., Redemann, J., and Wenny, B.: Evaluation of the MODIS aerosol retrieval over ocean and land during CLAMS, J. Atmos. Sci., 62(4), 974-992, 2005.

Levy, R. C., Remer, L. A., and Dubovik, O.: Global aerosol optical properties and application to Moderate Resolution Imaging Spectoradiometer aerosol retrieval over land, J. Geophys. Res., 112, D13210, doi:10.1029/2006JD007815, 2007.

Li, F. and Ramnathan, V.: Winter to summer monsoon variation of aerosol optical depth over the tropical Indian Ocean, J. Geophys. Res., 107, 4284, doi:10.1029/2001JD000949, 2002.

Martonchik, J. V.: Determination of aerosol optical depth and land surface directional reflectances using multiangle imagery, J. Geophys. Res., 102(D14), 17015-17022, 1997.

Menon, S., Hansen, J., Nazarenko, L., and Lou, Y.: Climatic effects of black carbon aerosols in China and India, Science, 297, 22502253, 2002.

Mishchenko, M. I., Cairns, B., Hansen, J. E., Travis, L. D., Burg, R., Kaufman, Y. J., Martins, V., and Shettle, E. P.: Monitoring of aerosols forcing of climate from space: analysis of measurement 
requirements, J. Quant. Spectrosc. Radiat. Transf., 88, 149-161, 2004.

Misra, A., Jayaraman, A., and Ganguly, D.: Validation of MODIS derived aerosol optical depth over Western India, J. Geophys. Res., 113, D04203, doi:10.1029/2007JD009075, 2008.

Moorthy, K. K. and Satheesh, S. K.: Characteristics of aerosols over a remote island, Minicoy in the Arabian Sea: Optical properties and retrieved size characteristics; Q. J. Roy. Meteor. Soc., 126, 81-109, 2000.

Moorthy, K. K. and Saha, A.: Aerosol study during INDOEX: Observations of enhanced aerosol activity over the Mid Arabain Sea during the northern winter, J. Atmos. Sol. Terr. Phys., 62, 65-72, 2000.

Moorthy, K. K., Suresh Babu, S., and Satheesh, S. K.: Aerosol characteristics and radiative impacts over the Arabian Sea during the inter monsoon seasons: Results from ARMEX field Campaign, J. Atmos. Sci., 62, 192-206, 2005.

Morys, M., Mims III, F. M., Hagerup, S., Anderson, S. E., Baker, A., Kia, J., and Walkup, T.: Design, calibration, and performance of MICROTOPS II handheld ozone monitor and sun photometer, J. Geophys. Res., 106(D13), 14573-14582, 2001.

Nair, S. K., Parameswaran, K., and Rajeev, K.: Seven year satellite observations of the mean structures and variabilities in the regional aerosol distribution over the oceanic areas around the Indian subcontinent, Ann. Geophys., 23, 2011-2030, 2005, http://www.ann-geophys.net/23/2011/2005/.

Parameswaran, K.: Atmospheric aerosols and their radiative effects, PINSA, 64(A3), 245-266, 1998.

Porter, J. H., Miller, M., Pietras, C., and Motell, C.: Ship-based Sun photometer measurements using Microtops sun photometers, J. Atmos. Oceanic Technol., 18, 765-774, 2001.

Prospero, J. M.: Mineral and sea salt aerosol concentrations in various oceanic regions, J. Geophys. Res., 84(2), 725-731, 1979.

Prospero, J. M., Charlson, R. J., Mohnen, V., Jaenicke, R., Delany, C., Moyere, J., Zoller, W., and Rahn, K.: The atmospheric aerosol system - an overview, Rev. Geophys. Space Phys., 21, 1607-1629, 1983.

Raes, F., Bates, T., and McGovern, F.: The 2nd Aerosol Characterisation Experiment (ACE-2): General overview and main results, Tellus, 52B, 111-125, 2000.

Ramanathan, V., Crutzen, P. J., Lelieveld, J., Mitra, A. P., et al.: Indian Ocean Experiment: An integrated analysis of the climate forcing and the effects of the great Indo-Asian haze, J. Geophys. Res., 106, 28371-28398, 2001.

Remer, L. A., Tanre, D., Kaufman, Y. J., Ichoku, C., Mattoo, S., Levy, R., Chu, D. A., Holben, B., Dubovik, A., Smirnov, A., Martins, J. V., Li, R.-R., and Ahmad, Z.: Validation of MODIS aerosol retrieval over ocean, Geophys. Res. Lett., 29(12), MOD3, doi:10.1029/2001GL013204, 2002.
Remer, L. A., Kaufman, Y. J., Tanre, D., Mattoo, S., Chu, D. A., Martins, J. V., Li, R.-R., Ichoku, C., Levy, R. C., Kleidman, R. G., Eck, T. F., Vermote, E., and Holben, B. N.: The MODIS aerosol algorithm, products and validation, J. Atmos. Sci., 62, 947-973, 2005.

Satheesh, S. K. and Moorthy, K. K.: Aerosol characteristics over coastal regions of the Arabian Sea, Tellus, 49B, 417-428, 1997.

Satheesh, S. K. and Srinivasan, J.: Enhanced aerosol loading over Arabian Sea during the pre-monsoon season: Natural or anthropogenic?, Geophys. Res. Lett., 29(18), 1874, doi:10.1029/2002GL015687, 2002.

Satheesh, S. K., Srinivasan, J., and Moorthy, K. K.: Contribution of sea-salt to aerosol optical depth over the Arabian Sea derived from MODIS observations, Geophys. Res. Lett., 33, L03809, doi:10.1029/2005GL024856, 2006.

Smirnov, A., Holben, B. N., Dubovik, O., O’Neil, N. T., Eck, T. F., Westphal, D. L., Goroch, A. K., Pietras, C., and Slutsker, I.: Atmospheric aerosol optical properties in the Persian Gulf, J. Atmos. Sci., 59, 620-634, 2002.

Smirnov, A., Holben, B. N., Eck, T. F., Dubovik, O., and Slutsker, I.: Effect of wind speed on columnar aerosol properties at Midway island, J. Geophys. Res., 108(D24), 4802, doi:10.1029/2003JD003879, 2003.

Spiegel, M. R. and Stephens, L. J.: Theory and problems of statistics, Tata McGraw-Hill publishing limited, New Delhi, 345-349 pp., 3rd Edition, 2000.

Suresh Babu, S., Moorthy, K. K., and Satheesh, S. K.: Aerosol black carbon over Arabian Sea during inter monsoon and summer monsoon seasons, Geophys. Res. Lett., 31, L06104, doi:10.1029/2003GL018716, 2004.

Tanre, D., Kaufman, Y. J., Herman, M., and Mattoo, S.: Remote sensing of aerosol properties over oceans using the MODIS/EOS spectral radiances, J. Geophys. Res., 102, 16971-16988,1997.

Tripathi, S. N., Dey, Sagnik, Chandel, A., Srivastava, S., Singh, Ramesh P., and Holben, B. N.: Comparison of MODIS and AERONET derived aerosol optical depth over the Ganga Basin, India, Ann. Geophys., 23, 1093-1101, 2005, http://www.ann-geophys.net/23/1093/2005/.

Twomey, S.: The influence of pollution on the short wave albedo of clouds, J. Atmos. Sci., 34, 1149-1152, 1977.

Vinoj, V. and Satheesh, S. K.: Measurememt of aerosol optical depth over Arabian Sea during summer monsoon season, Geophys. Res. Lett., 30(5), 1263, doi:10.1029/2002GL016664, 2003.

Vinoj, V., Suresh Babu, S., Satheesh, S. K., Krishna Moorthy, K., and Kaufman, Y. J.: Radiative forcing of aerosols over the Bay of Bengal region derived from shipborne, island-based, and satellite (Moderate-Resolution Imaging Spectroradiometer) observations, J. Geophys. Res., 109, D05203, doi:1029/2003JD004329, 2004. 